\title{
Brzozowskianism: The Trouble with the "Great" Brzozowski and His Followers
}

\author{
Dorota Kozicka
}

References to Brzozowski as an author who had enough courage and critical power to tackle the reality of his times and rework dominant worldviews have appeared almost continually for more than a century, which has invariably triggered heated debates on his actual ideological stances. This problem has been repeatedly debated, including in one of my own earlier texts which argues for the special place of Brzozowski within the landscape of Polish literary criticism. ${ }^{1}$ The critics and intellectuals who have taken up Brzozowski's thought and have treated his texts as a benchmark for their own intellectual work are usually referred to as brzozowczycy - "Brzozowskists" - and although today the term has a slightly outdated ring, it has preserved its positive meaning. A very different case is brzozowszczyzna, "Brzozowskianism," a notion that I would like to analyze here more closely by looking at the elements of Brzozowski's life and work

1 A bibliography of texts which analyse Brzozowski's influence on Polish intelligentsia can be found in Krzysztof Fiołek's article "Kłopotliwa obecność Stanisława Brzozowskiego w kilku przygodach ideologicznych inteligencji polskiej" [Stanisław Brzozowski's troublesome presence in several ideological adventures of the Polish intelligentsia], Ruch Literacki 4/5 (2005): 383-392. Cf. also Marian Stępień, "Spór o spuściznę po Stanisławie Brzozowskim w latach 1918-1939" [The controversy about Stanisław Brzozowski's legacy in 1918-1939] (Kraków: Wydawnictwo Literackie, 1976); Maciej Urbanowski, "Brzozowski i powojenna krytyka literacka. Uwagi wstępne" [Brzozowski and post-war literary criticism: preliminary remarks], Dekada Literacka 4 (2008); Dorota Kozicka, "Brzozowski - pobożne życzenie krytyki” [Brzozowski: criticisms' wishful thinking], in Dorota Kozicka, Krytyczne (nie)porzadki. Studia o wspótczesnej krytyce literackiej w Polsce [Critical (dis)ordering: Studies on contemporary literary criticism in Poland] (Kraków: Universitas, 2012). 
which gave the term its connotations, and, above all, at its actual meaning. Has it changed throughout history, or does it rather, like żeromszczyzna (Żeromskianism), contain a fixed set of characteristics understood relatively unambiguously by all? Seemingly obvious as it is (after all, we do feel intuitively what could be meant by this notion), the matter becomes more complicated once we take a closer look at the specific context in which the term of brzozowszczyzna is used. A literary critic testifies to its vague, nondescript character stating that when "[1] ooking for the acolytes of brzozowszczyzna, however understood, it is worthwhile to ask about critics from outside this circle, i.e., those not reading, not susceptible to, not in dialogue with, not fascinated by the heritage of the author of Legenda Młodej Polski."2

On the other hand, this notion can also be found in unambiguous contexts such as when used with a particular meaning in mind as argued by Maciej Urbanowski who states that "there was Brzozowski, and there was brzozowszczyzna," which thus distinguishes the work of Brzozowski from its imitations, them being either inept or cynical. ${ }^{3}$ When later asked in an interview for Fronda (Fronde) "What would brzozowszczyzna look like today?", Urbanowski replied as follows:

Of course, it is hard to speak here of any normative formula. Of a correctly or incorrectly understood brzozowszczyzna. In any case, the very word brzozowszczyzna sounds pejorative and condescending. Certainly, there will not be a new Brzozowski, a second or third

2 Anna Legeżyńska, "Fantazja lekturowa o nie-czytelniku Brzozowskiego" [A reader's fantasy about a non-reader of Brzozowski], in "Ostać się wobec chaosu". Prace ofiarowane Profesorowi Tomaszowi Lewandowskiemu ["To survive in the face of chaos": Studies to honor professor Tomasz Lewandowski] (Poznań: Wydawnictwo Naukowe UAM, 2013), 288.

3 "Czy jest koniunktura na Brzozowskiego? Ze Sławomirem Sierakowskim i Maciejem Urbanowskim rozmawia Cezary Michalski” [Is Brzozowski fashionable? Sławomir Sierakowski and Maciej Urbanowski in conversation with Cezary Michalski], in: Brzozowski. Przewodnik krytyki politycznej (Warszawa: Krytyka Polityczna, 2011), 61. The full context of this sentence is as follows: "The last such attempt of using him was, I think, Kornhauser's and Zagajewski's Świat nieprzedstawiony [The unrepresented world], and then Andrzej Pawluczuk's Rozbiory [Construals]. The latter was sharply criticised by Tomasz Burek, who called it a caricature of Brzozowski's method. I do not know whether this critique was deserved, but certainly in our literature there were many rentiers who cashed up, conveniently and usually with impunity, on the thought of the author of Ptomienie [Flames]. There was Brzozowski, and there was brzozowszczyzna [...]." 
Brzozowski. Surely, Czapliński to some extent refers to Brzozowski, but he puts his emphasis on the progressive, Promethean Brzozowski, the one who "exchanges" Poland for a different Poland, "liberated" from the burden of tradition, religion. What shall remain for us of this exchange? Not much, I am afraid. But there is also for example the alreadymentioned Tomasz Burek, who refers to the late Brzozowski, already clearly detached from that Polish progressivism, those sorry Youngbloods ${ }^{4}$ reading at breakfast American feminists and French philosophers. Thus, Burek is trying to find a trend in the Polish tradition, which, starting from 1905, has combined revolutionary and national, political and metaphysical tendencies. Perhaps this is our alternative to leftist brzozowszczyzna, this shows us how to read literature today and what kind of Polishness to think about. ${ }^{5}$

In Urbanowski's statements, the meaning of the term in question is clearly limited to such reading as the imitation of or fascination with Brzozowski's works (to briefly recall Legeżyńska's enumeration), which, according to the Krakówbased scholar, is not in line with the thoughts or intentions of Brzozowski himself. Although it certainly seems open to question how this very "unorthodoxy" can be identified (a problem I will return to later in this essay), here it is worth noticing that Urbanowski's emphasis on the pejorative meaning of brzozowszczyzna corresponds to the common understanding of such name derivatives in Polish. The dictionary Stownik poprawnej polszczyzny (Dictionary of Correct Polish) defines the meaning of the -izna and -yzna suffixes, which feature nouns derived from adjectives and nouns, with reference to three semantic categories. The first of these is in combination with the names of countries,

[...] a language, or a set of features of a given country (i.e., fashion, mentality, manner of being), as in polszczyzna, francuszczyzna, niemczyzna [derivatives from the Polish names for Poland, France, and Germany respectively]. In the case of nouns derived from qualitative adjectives, they [these suffixes] add to the lexical base a sense of gluttony or excess, i.e., jaskrawizna [from jaskrawy, gaudy (of a colour)], szarzyzna [from szary, grey (dull)], dlużyzna [from dtugi, long (in a temporal sense)]. In the case of derivatives from personal proper names, they create names of intellectual, artistic, or political formations repre-

4 The Youngbloods (Polish "Młodziakowie") were a fictional progressive Polish family of the interwar period, portrayed by Witold Gombrowicz in his novel Ferdydurke. Their name has since been used by critics to refer to the thoughtless following of new trends.

5 "Religijny i metafizyczny socjalista. Tomasz Rowiński rozmawia z Maciejem Urbanowskim" [A religious and metaphysical socialist. Maciej Urbanowski in conversation with Tomasz Rowiński], Fronda 65/4 (2012). http://www.pismofronda.pl/ religijny-i-metafizyczny-socjalista 
sented by their authors, e.g., towiańszczyzna, wyspiańszczyzna, żeromszczyzna [from Towiański, Wyspiański, and Żeromski respectively], and they are often marked negatively. ${ }^{6}$

What is worth considering in reference to this dictionary definition is whether the third category does not also contain the connotations of the previous two. It is in this sense that I would like to discuss brzozowszczyzna in this paper.

\section{Brzozowskianism vs. Brzozowski}

As soon as it was coined, the label brzozowszczyzna was used to refer to Brzozowski's works and/or his imitators and followers. In the case of Brzozowski's supporters, these two usages are disjunctive, while for his adversaries, his influence on readers becomes an important argument for opposing him. In his famous text "Brzozowski jako wychowawca" (Brzozowski as an Educator), Ludwik Fryde concludes his analysis of the educational consequences of Legenda Młodej Polski and other writings by Brzozowski as follows:

Brzozowszczyzna is a cultural ailment no less dangerous than żeromszczyzna. This ideology does not lack consistency or even historical intuition - it is partial truth, yet based on a fundamental lie. For it is unwittingly assumed that one has the unquestionable right of leadership of the people. The intelligentsia believes that its irresponsible protests in the name of humanitarianism are permissible, and when it abandons all scruples, it thinks that it is allowed to seek power by all means, and retain it at any cost. And hence, brzozowszczyzna is a reflection of żeromszczyzna. It creates, despite the apparent power and consistency of its ideological program, a school of political hysteria, a school of social mercenarism. $^{7}$

Writing in Nowe Drogi (New Ways), an ideological organ of the Polish Workers' Party and the Polish United Workers' Party, Paweł Hofman takes a different position than Fryde, stating,

6 Andrzej Markowski, ed., Stownik poprawnej polszczyzny PWN (Warszawa: PWN, 2010), 153.

7 Ludwik Fryde, "Brzozowski jako wychowawca (Z powodu wydania Legendy Młodej Polski)" [Brzozowski as an educator (Upon the occasion of the publication of Legenda Młodej Polski)], Ateneum 1 (1938). Quoted after the reprint in: Jest Bóg, żyje prawda. Inna twarz Stanisława Brzozowskiego, ed. Maciej Urbanowski (Kraków: Fronda, 2012), 205. 
In many circles of the Polish intelligentsia, even in socialist circles, there still hangs the stench of Brzozowski's views or ideology. There exists the legend created by Brzozowski and the legend created about Brzozowski. The dissipation of both of these legends, the liberation of Polish intellect from the taint of brzozowszczyzna, will facilitate a proper outlook on the last half-century of our history. ${ }^{8}$

Brzozowski's broadly-understood ideology is fundamental for both critics and no matter how they define it, it becomes the object of their criticism. As demonstrated by Fryde, Brzozowski's attitude can be considered even more dangerous as it is expressed in a manner that is appealing to the reader, producing a particular mode of reading and thinking. Pointing out Brzozowski's style, the type of reader who would reach for Legenda Młodej Polski, and the way the book is received, Ludwik Fryde touches on issues that seem no less important for our reflections on brzozowszczyzna than on Brzozowski's particular ideas and opinions. It is therefore impossible to separate Brzozowski's ideas from the manner he conveyed them and also from their reception, which includes the imitations that usually bring the features of the orginal into its sharpest relief.

A different view on the influence of Brzozowski's writings comes from Eustachy Czekalski- the first person to use the word brzozowszczyzna, as far as I know. He mentions "the senile radicalism of the literary-critical Brzozowszczyzna persisting in a couple of already bald and grey skulls." Using Suchodolski's book on Brzozowski as his point of departure, the author tries to contrast the "true" value of Brzozowski with those of his imitators who maintained left-wing views. He claims that "it behooves and it is worthwhile" to read Brzozowski, "yet one should not take from him his positive assertions, but rather his melodies and tone, the intensity of his spirit." Jan Emil Skiwski also refers to Brzozowski's followers and imitators in his 1928 essay on scientific and prophetic criticism. Deprecating the latter, Skiwski distinguishes between "the invariably deep, costly, and even painfully intense engorgement of contemporary philosophy," characteristic of Brzozowski himself, and the "improvisations à la Brzozowski." He forgives Brzozowski for his "immensely demoralizing” mannerisms ("artificial dramatization of language," "jargon of philosophical emotions" instead of direct statements, and suggestions instead of arguments) for the sake of "his talent" and originality. It was in this essay that Skiwski claimed that the unquestionable originality of Brzozowski's thought was taken by his contempo-

8 Paweł Hoffman, "Legenda Stanisława Brzozowskiego" [The legend of Stanisław Brzozowski], Nowe Drogi 2 (1947): 103.

9 Eustachy Czekalski, "Brzozowszczyzna” [Brzozowskianism], Antena. Zjawisk życiasztuki-literatury 8 (1933): 2. 
raries and "transformed into a little pocketsize codex" from which they drew ready-made formulas for depth, "vitality," and "singularity." ${ }^{, 10}$ Several decades later, Marek A. Cichocki repeated Skiwski's argument, directing this description of brzozowszczyzna against his ideological opponents:

When one follows the Polish dispute today, one can get the impression that brzozowszczyzna has entered into the circulation of public debate for good, giving it sometimes a downright, unbearable, self-accusatory tone. By brzozowszczyzna, I mean here a certain attitude characteristic of the Polish intelligentsia, and the whole ensuing set of arguments critical of Polishness (their congenial examples can be found in "Polska zdziecinniała" [Poland Gone Puerile]). It is a form of moral blackmail, readily employed by representatives of our intelligentsia in regard to their less-enlightened fellow citizens who are shamed by their alleged non-modernity and lack of understanding of the modern world. This attitude involves many hidden, never-overcome complexes, and many unjustified simplifications. Describing the phenomenon of brzozowszczyzna in the interwar period, Jan Emil Skiwski noticed that the unquestionable originality of Brzozowski's thought was taken by his contemporaries and "transformed into a little pocketsize codex," from which they could draw ready-made formulas. Also today for example, the compound "PolishCatholic," borrowed mainly from Brzozowski, is repeated like a Hindu mantra by all critics of traditional Polishness and defenders of a particularly understood modernity. It is not always, however, that brzozowszczyzna manifested in this way has anything to do with Brzozowski's thought. Hence, sometimes it is worth distinguishing it from Brzozowski's work, which is anything but a handy pocket-size codex. ${ }^{11}$

In this sense-as imitation reducing the original model; as settling for a stereotypical, superficial repetition of somebody else's views or ways of acting; as imitating a particular intellectual pose, yet understood as significantly distinct from Brzozowski's actual writings-brzozowszczyzna acquires a character that is predominantly used by right-wing authors to refer to leftist-oriented intellectuals who evoke Brzozowski's patronage (or in whose works any "common places" can be found, as is the case with Czapliński, as mentioned by Urbanowski). Thus, the main function of the term brzozowszczyzna is to discredit ideological

10 Jan E. Skiwski, "O krytyce naukowej i profetycznej” [On scientific and prophetic criticism], Myśl Narodowa 15 (1928); reprinted in: idem, Na przełaj oraz inne szkice o literaturze i kulturze, ed. Maciej Urbanowski (Kraków: Wydawnictwo Literackie, 1999), 36.

11 Marek A. Cichocki, "Brzozowski - suwerenność w kulturze" [Brzozowski: sovereignty in culture], Znak 2 (2001); reprinted in: ,Jest Bóg żyje prawda”. Inna twarz Stanistawa Brzozowskiego, $361 \mathrm{f}$. 
opponents, which makes it all the more interesting that most authors who use this term do seem to appreciate the diversity of Brzozowski's views and to understand his influence on various attitudes and ways of thinking. Urbanowski himself, who has used brzozowszczyna most often, argues on many occasions that Brzozowski's undeniable greatness is manifested in the fact that his writings have allowed many generations of Polish intelligentsia from multiple ideological "options" to define themselves, and that in this way the critic has become a crucial role-model for different intellectual milieus and thinkers. In this case, however, the belief in the "eternal sources of creative capacities" contained in Brzozowski's works is combined with a firm idea of what can and what cannot be considered a proper use of these sources and it is motivated by the desire to defend Brzozowski against mediocre followers who simplify his thought. Used in this sense, the term brzozowszczyzna can be used above all in ideological disputes, but it also serves as a term in the struggle over Brzozowski's true critical legacy. ${ }^{12}$

12 This way of thinking has been aptly demonstrated by Cichocki who writes that "one should combat brzozowszczyzna as an intellectual pose, but the thought of Brzozowski himself is worth being continuously engaged with." He then goes on to explain that "on the other hand, it is difficult to pretend not to see that Brzozowski's concept of modernity was always combined with an attitude of radical criticism - without it, it loses its actual meaning. This is not very distant from the conviction that a spiritual transformation of the Polish people can only take place if the old world is reduced completely to rubble. This argument was already used by many Polish intellectuals as an explanation of their enchantment with Stalinism in the early 1950s. The same lack of consideration with respect to tradition and intemperate criticism of one's own national community that would lead to its destruction later became the main feature of brzozowszczyzna as a critical approach popular after 1989. However, this attitude assumes a significant reduction of the themes of Brzozowski's work, focusing as it does almost exclusively on his critique of Polish traditionalism in the form of nobility culture and Catholicism. What disappears when such a perspective is adopted are all the motifs of Brzozowski's critique of bourgeois liberalism and its derivative forms of culture that could contribute to an unfavorable description of the Polish parvenu middle-class today. [...] One may get the impression that Brzozowski's critical grandiosity often sets the same trap for Poles, namely the trap of Polish intellectual parochialism. So suggestive is Brzozowski's critique of Polishness that anyone who dislikes something about the Poles can identify with it. His work is so rich that it can inspire both wise and stupid criticism of Polishness." (Cichocki, "Brzozowski - suwerenność," 374f.). 


\section{The Power of Immaturity}

The two uses of brzozowszczyzna present somewhat different perspectives with the first referring to Brzozowski himself, centered not so much on his ideas as on his critical approach and his way of performing intellectual work. The second is used to assail Brzozowski's imitators who do focus on Brzozowski's views overall, although they concentrate somewhat on condemning his emotions and rhetoric.

I would like to clarify this negative perspective by defining the notion of brzozwszczyzna following the example of zeromszczyzna ${ }^{13}$ by moving from a strictly evaluative formula to a more descriptive one, which would nevertheless take into account the pejorative character of this term. Without ignoring the obvious accusations put forth by different ideological camps against Brzozowski's particular views, I want to find in critical and polemical statements the caracteristics that are commonly ascribed to Brzozowski's work. These can refer to his ideological stance, critical temperament, way of reading, and style of writing. After all, today it would be difficult to think of brzozowszczyzna without taking into account Brzozowski's readers, critics, and followers; yet it would be equally difficult to forget that it was the characteristic performativity of his influential texts.

The most salient element defining brzozowszczyzna is undoubtedly Brzozowski's changing views and beliefs and his temperament as a driven planner and mender of the world. Brzozowski's style is unique because of the vividness and sharpness of his claims, his characteristic manner of arriving at particular views, and the changeability of his opinions and thought. From analyzing various texts, one can distinguish some vivid descriptions of these negatively perceived features. An example of this is the "critical' St. Vitus dance," ${ }^{, 14}$ which is

13 Cf. the entry "Żeromszczyzna," in Słownik terminów literackich [Dictionary of literary terms], $3^{\text {rd }}$ ed., ed. Janusz Sławiński (Wrocław: Zakład Narodowy im. Ossolińskich, 1998), 640, and Stanisław Sierotwiński’s Stownik terminów literackich, $4^{\text {th }}$ ed. (Wrocław: Zakład Narodowy im. Ossolińskich, 1986), 306.

14 Stefan Żeromski wrote in 1918, "Fierce, phenomenally hasty, fitful reading, often not out of internal need but out of snobbism, which he himself admits, to impress the literary mob by the unheard of multi-directionality of reading, moved his mania of adorations from Sorel as far as to the writings of Cardinal Newman. Every book he read smote him to such a degree that he cut veritable capers among multifarious authors. [...] This 'critical' St. Vitus dance practiced by Stanisław Brzozowski made a great impression and even still impresses certain writing spheres in Poland.” Stefan Żeromski, Dzieła. Pisma różne [Works. Various writings], vol. 2: Pisma literackie i krytycz- 
a pejorative rendering of one of the most often underscored characteristics of Brzozowski's critical work, i.e., the eclecticism, changeability, and superficiality of his reading; his unhealthy ambition to keep au courant with Western novelties. Another feature of Brzozowski that is strongly connected with his reading is the "harvesting of thoughts from books." Zygmunt Wasilewski referred to his reading as "literary emptiness" 15 and accused Brzozowski of cherishing the beauty of ideas rather than truth. Fryde adopts a similar tone by describing Legenda Młodej Polski as "sick and contagious intellectual hedonism" and accused Brzozowski of relishing in infinite intellectual associations. ${ }^{16}$ Similar views are expressed today in the indictments by the communist left against the over-intellectualized elitism of the members of the Krytyka Polityczna circle who have been influenced by Brzozowski's thought. Another such feature referring somewhat to the literary roots of Brzozowski's thought and above all to the style of his texts is the phenomenon metaphorically described by Fryde as "the rushing of grand words and grand problems."17 This phrase touches on Brzozowski's bombastic style, the settling of intellectual problems at the level of existential resolutions, and his emotional tone.

It seems that it is in Brzozowski's way of shaping his critical discourse that we will find significant markers of the incriminated brzozowszczyzna; a style of writing capable of inspiring radical solutions. These texts are to some "a volcano of thoughts, feelings, and pursuits"18 while others describe it as "a raw,

ne [Literary and critical writings] (Warszawa 1963), 73. The accusations of literary snobbism and eclecticism already appeared during Brzozowski's lifetime, for example in Jan Lemański's rhymed pamphlet entitled Erudyta [The erudite] Widnokręgi 10,2 (1910): 340f., reprinted in: "Chamuly", "gnidy", "przemilczacze”... Antologia dwudziestowiecznego pamfletu polskiego ["Boors," "lice," "dissemblers"... An anthology of the twentieth-century Polish pamphlet], ed. Dorota Kozicka (Kraków: Universitas, 2010).

15 Zygmunt Wasilewski, "Idea pracy” [The idea of labor], in Dyskusje (Poznań: Księgarnia Św. Wojciecha, 1926); reprinted in: Jest Bóg, żyje prawda..., 113f.

16 Fryde, "Brzozowski jako wychowawca," 188.

17 "The direct current of high emotional voltage, the rushing of grand words and grand problems, and the unclear yet very suggestive calls to action made us passionately delve into Legenda, with flushed cheeks even before we grasped its meaning." Ibid., 187.

18 Silvester [s. Teresa Landy], "Stanisława Brzozowskiego drogi do Rzymu" [Stanisław Brzozowski's Roads to Rome], Verbum III (1935), reprinted in: Jest Bóg, żyje prawda..., 145. 
revolutionary element."19 Still others stress the performative power of Brzozowski's extremely passionate way of dealing with literature and criticism. Such features are evidently connected with the characteristics of Brzozowski's thought which he best described when he wrote that he was always unready and immature. ${ }^{20}$ This description is very fitting in that it encompasses both Brzozowski's tendency to record all of his thoughts, even while reading. He transcribes the thinking process rather than complete thoughts and to write in a youthful state of emotions by treating literature and philosophy as a "territory of quasi-life expansion." ${ }^{21}$ As a consequence, the most "zealous inheritors" ${ }^{\text {"22 }}$ of the critic were young intellectuals. Characteristic among the numerous texts referencing the youthful character of both Brzozowski's writings and their reception is a review of Tomasz Burek's second book of literary criticism in which the reviewer expresses his concern that unlike other critics who went through a Brzozowski phase, Burek never grew out of his. ${ }^{23}$ Another example would be Adam Zagajewski, who during the period of programmatic articles of the Polish New Wave, wrote pamphlet-like texts evoking Brzozowski, whereas a dozen or so years later in 1985 , one of his means of grounding the radical change of his attitude was a wholesale deprecation of Brzozowski and his imitators:

Those who put on the mask of Stanisław Brzozowski, whether for a moment or forever, [...] bring to life a phantom of literature, a poltergeist of art (it is easy to tell an artist from an educator - the former always speaks on his own behalf, the latter feels a generation, a nation, a social class, humanity, or a poetic group standing behind him). I can imagine where the charm of Brzozowski's heritage stems from; it seems to promise a strict, conceptual power over literature, a government of souls, and more - of chosen souls, those which govern other souls. Conceptual shortcuts, reductions, and postulates crisscross here like orders, like signals of a hunting horn. ${ }^{24}$

It is the feverish emotionality - a combination of thoughts awakened and led on in multiple directions, of intellectual upsurges rather than finished, precisely-

19 Krzysztof Fiołek, "Kłopotliwa obecność," 387.

20 Brzozowski, Legenda Młodej Polski, 289.

21 Fryde, Brzozowski jako wychowawca, 192.

22 For Marta Wyka's phrasing, cf.: “Głos Brzozowskiego. Rozmowa redakcyjna” [Brzozowski's Voice. Editors' discussion panel], Dekada Literacka 230 (2008). http:// www.dekadaliteracka.pl/?id=4660

23 Cf. Zbigniew Bieńkowski, "Klucze” [Keys], Twórczość 2 (1974): 95.

24 Adam Zagajewski: Solidarność i samotność [Solidarity and solitude] (Warszawa: Fundacja Zeszytów Literackich, 2002), 76. 
formulated mental constructions, a combination juxtaposed with the presence, constantly manifested in the texts, of Brzozowski fighting for his views and for a better reality that seems to constitute the special mixture comprising brzozowszczyzna. These features arguably prevented posterity from seeing an unquestionable greatness in Brzozowski and it contributed to the fact that he left a mark on Polish contemporary culture and broadly understood criticism not as an unchallenged authority but rather as a catalyst for radically different views and ideological stances. Yet it is thanks to these same features, I believe, that Stanisław Brzozowski still remains inspiring, intriguing, not quite read to the full...

Translated by Zofia Ziemann

\section{WORKS CITED}

Bieńkowski, Zbigniew. “Klucze.” Twórczość 2 (1974): 93-96.

Cichocki, Marek A. "Brzozowski - suwerenność w kulturze.” In ”Jest Bóg żyje prawda." Inna twarz Stanisława Brzozowskiego, edited by Maciej Urbanowski, 361-377. Kraków: Fronda, 2012.

Czekalski, Eustachy. “Brzozowszczyzna.” Antena. Zjawisk życia-sztuki-literatury 8 (1933): 2.

Fiołek, Krzysztof. “Kłopotliwa obecność Stanisława Brzozowskiego w kilku przygodach ideologicznych inteligencji polskiej." Ruch Literacki 4/5 (2005): 383-392.

Fryde, Ludwik. "Brzozowski jako wychowawca (Z powodu wydania Legendy Młodej Polski)." In “Jest Bóg żyje prawda." Inna twarz Stanisława Brzozowskiego, edited by Maciej Urbanowski, 181-214. Kraków: Fronda, 2012.

““Głos Brzozowskiego.' Rozmowa redakcyjna.” Dekada Literacka (2008). http: //www.dekadaliteracka.pl/?id=4660

Hoffman, Paweł. "Legenda Stanisława Brzozowskiego.” Nowe Drogi 2 (1947): 104-136.

Kozicka, Dorota. "Brzozowski - pobożne życzenie krytyki." In Krytyczne (nie)porządki. Studia o współczesnej krytyce literackiej w Polsce, edited by Dorota Kozicka, 82-122. Kraków: Universitas, 2012.

Legeżyńska, Anna. "Fantazja lekturowa o nie-czytelniku Brzozowskiego." In "Ostać się wobec chaosu”. Prace ofiarowane Profesorowi Tomaszowi Lewandowskiemu, edited by Radosław Okulicz-Kozaryn, and Mateusz Bourkane, 285-302. Poznań: Wydawnictwo Naukowe UAM, 2013. 
Lemański, Jan. "Erudyta." In "Chamuly”, "gnidy”, "przemilczacze”... Antologia dwudziestowiecznego pamfletu polskiego, edited by Dorota Kozicka, 209-212. Kraków: Universitas, 2010.

Markowski, Andrzej, ed. Stownik poprawnej polszczyzny PWN. Warszawa: PWN, 2010.

Silvester [s. Teresa Landy], "Stanisława Brzozowskiego drogi do Rzymu." In “Jest Bóg, żyje prawda." Inna twarz Stanistawa Brzozowskiego, edited by Maciej Urbanowski, 145-164. Kraków: Fronda, 2012.

Sierotwiński, Stanisław, ed. Stownik terminów literackich. $4^{\text {th }}$ ed. Wrocław: Zakład Narodowy im. Ossolińskich, 1986.

Skiwski, Jan Emil. "O krytyce naukowej i profetycznej." In idem, Na przełaj oraz inne szkice o literaturze i kulturze, edited by Maciej Urbanowski, 3138. Kraków: Wydawnictwo Literackie, 1999.

Sławiński, Janusz (ed.). Stownik terminów literackich. $3^{\text {rd }}$ ed. Wrocław: Zakład Narodowy im. Ossolińskich, 1998.

Stępień, Marian. Spór o spuściznę po Stanistawie Brzozowskim w latach 19181939. Kraków: Wydawnictwo Literackie, 1976.

Urbanowski, Maciej. "Brzozowski i powojenna krytyka literacka. Uwagi wstępne." Dekada Literacka 4 (2000): 24-37.

- . "Czy jest koniunktura na Brzozowskiego? Ze Sławomirem Sierakowskim i Maciejem Urbanowskim-rozmawia Cezary Michalski." In Brzozowski. Przewodnik krytyki politycznej, 56-71. Warszawa: Krytyka Polityczna, 2011.

- (ed.). “Jest Bóg żyje prawda.” Inna twarz Stanistawa Brzozowskiego. Kraków: Fronda, 2012.

- "Religijny i metafizyczny socjalista. Tomasz Rowiński rozmawia z Maciejem Urbanowskim." Fronda 65, 4 (2012): 255-272.

http://www.pismofronda.p1/religijny-i-metafizyczny-socjalista

Wasilewski, Zygmunt. "Idea pracy." In "Jest Bóg, żyje prawda." Inna twarz Stanistawa Brzozowskiego, edited by Maciej Urbanowski, 105-115. Kraków: Fronda, 2012.

Zagajewski, Adam. Solidarność i samotność. Warszawa: Fundacja Zeszytów Literackich, 2002.

Żeromski, Stefan. Dzieła. Pisma różne, vol. 2: Pisma literackie i krytyczne. Warszawa: Czytelnik, 1963. 